\title{
Study of electrical conductivity and hardness of ternary Ag-Ge-Sb system alloys and isothermal section calculation at $300^{\circ} \mathrm{C}$
}

\author{
M. Premović ${ }^{1 *}$, D. Manasijević ${ }^{2}$ D. Minić ${ }^{1}$, D. Živković ${ }^{2}$ \\ ${ }^{1}$ University in Priština, Faculty of Technical Science, Kos. Mitrovica, Serbia \\ ${ }^{2}$ University of Belgrade, Technical Faculty, Bor, Serbia
}

Received 11 October 2014, received in revised form 26 February 2015, accepted 16 March 2015

\begin{abstract}
In this paper, the comparative review of experimental and thermodynamic assessments of the ternary Ag-Ge-Sb system is presented. An isothermal section of the Ag-Ge-Sb system at $300^{\circ} \mathrm{C}$ has been extrapolated using optimized thermodynamic parameters for the constitutive binary systems. An experimental analysis of the microstructure was carried out using optical microscopy, scanning electron microscopy (SEM) and energy dispersive spectrometry (EDS). Results obtained by X-ray powder diffraction (XRD) methods (phases and lattice parameters) were compared with the results of the predicted phase equilibria. The hardness of selected alloys from the isothermal section at $300^{\circ} \mathrm{C}$ was determined using Vickers microhardness test and Brinell hardness test. The electrical conductivity of alloys from the isothermal section at $30{ }^{\circ} \mathrm{C}$ in the ternary $\mathrm{Ag}$-Ge-Sb system was determined experimentally. Good overall agreement between experimental and calculated values was obtained.
\end{abstract}

K e y w o r d s: crystal structure, electrical properties, microstructure, hardness test, scanning electron microscopy (SEM), annealing

\section{Introduction}

The ternary Ag-Ge-Sb system at $300^{\circ} \mathrm{C}$ has not been studied before. Previous investigations related to this ternary Ag-Ge-Sb system were done by the same authors [1] as this study. In recent years, there has been a significant increase of interest in the investigation of alloys based on Ge-Sb systems [2, 3]. This increase in research is based on the wide use of these alloys. Systems based on Ge-Sb are important for development of phase change memory materials [4], in electronics [5], because of their use in the optical and electronic devices [6] like materials for transistors, optical cables, semiconductors, integrated circuits, etc. $[7,8]$, in the modern technology of optical discs production, DVD, Blue-Ray discs, flash memories [9]. It is well known that silver and silver alloys represent excellent heat and electricity conductors. Common for germanium, silver and antimony is their application in the electronic industry. From this point of view, Ag-Ge-Sb ternary system represents one of the key alloy systems which has not yet been completely stud- ied. Besides the significant application of these alloys, understanding their properties is a matter of high importance $[10,11]$. The obtained results presented in this study should contribute to further development of this application area.

The constitutive binary systems are widely investigated, so the optimized thermodynamic parameters used in this study are taken from Wang et al. [12] for the Ag-Ge binary system, from Liu et al. [13] for the Ge-Sb binary system, and from Zoro et al. [14] for the Ag-Sb binary system.

Microstructural analysis was carried out by SEM using JEOL (JSM6460) microscope equipped with Oxford Instruments energy dispersive spectrometer and by light microscopy using OLYMPUS GX41 inverted metallographic microscope. Powder XRD data for phase identification of samples were recorded on a D2 PHASER (Bruker) powder diffractometer equipped with a dynamic scintillation detector and ceramic $\mathrm{X}$-ray $\mathrm{Cu}$ tube $(\mathrm{KFL}-\mathrm{Cu}-2 \mathrm{~K})$ in a $2 \theta$ range from $5^{\circ}$ to $75^{\circ}$ with a step size of $0.02^{\circ}$. The patterns were analyzed using the Topas 4.2 software, ICDD databases

*Corresponding author: tel.: +381 653005603; e-mail address: $\underline{\text { milena.premovic@gmail.com }}$ 
Table 1 . Considered phases and their crystal structures $[16,17]$

\begin{tabular}{lcccc}
\hline Thermodynamic database name & Common name & Space group symbol & Structure designation & Pearson symbol \\
\hline LIQUID & Liquid & & & \\
FCC_A1 & $(\mathrm{Ag})$ & $F m \overline{3} m$ & $\mathrm{~A} 1$ & $c F 4$ \\
HCP_A3 & $\zeta\left(\mathrm{Ag}_{9} \mathrm{Sb}\right)$ & $P 6_{3} / m m c$ & $\mathrm{~A} 3$ & $h P 2$ \\
AGSB_ORTHO & $\varepsilon\left(\mathrm{Ag}_{3} \mathrm{Sb}\right)$ & $P m 2$ & $\mathrm{~A} 7$ & $o P 8$ \\
RHOMBO_A7 & $(\mathrm{Sb})$ & $R \overline{3} m$ & $\mathrm{~A} 4$ & $c R 2$ \\
DIAMOND_A4 & $(\mathrm{Ge})$ & $F d \overline{3} m$ & $\mathrm{~A} 4$ \\
\hline
\end{tabular}

PDF2 (2013). Microhardness of the phases present in the microstructure was determined by Vickers microhardness tester SINOWON, model VEXUS ZHV$-1,000$ V. Hardness of the samples was measured using Brinell hardness tester INNOVATEST, model NEXUS 3001. Electrical conductivity measurements were carried out using Foerster SIGMATEST 2.069 eddy current instrument.

\section{Experimental procedure}

Investigated alloy samples were prepared from high-purity (99.999 wt.\%) Ag, Sb, and Ge, produced by Alfa Aesar (Germany). The prepared alloy samples with the weight of $3 \mathrm{~g}$ were sealed in evacuated quartz tubes and then heated to a temperature that is $50^{\circ} \mathrm{C}$ higher than the melting temperature of $\mathrm{Ag}$. The alloy samples were then cooled down to $300^{\circ} \mathrm{C}$ at the cooling rate of $5^{\circ} \mathrm{C} \mathrm{min}^{-1}$. The samples were kept at $300{ }^{\circ} \mathrm{C}$ for $300 \mathrm{~h}$ and then quenched in the water and ice mixture to preserve desired equilibrium at $300^{\circ} \mathrm{C}$.

The samples used for light microscopy, electrical conductivity measurements, and hardness tests were prepared by classic metallographic procedure without etching while the alloy samples used for SEM-EDS analysis were not sealed in the polymer.

\section{Results and discussion}

The isothermal section at $300^{\circ} \mathrm{C}$ for the ternary Ag-Ge-Sb system was extrapolated by using the only optimized thermodynamic parameters for constitutive binary systems from Wang et al. [12] for the Ag-Ge, from Liu et al. [13] for the Ge-Sb and from Zoro et al. [14] for the Ag-Sb binary system. Calculations were performed using PANDAT software [15].

The phases from the constitutive binary subsystems considered for thermodynamic binary-based prediction together with their corresponding Pearson symbols are given in Table 1.

\subsection{Microstructure analysis}

The microstructure of the alloys from the ternary

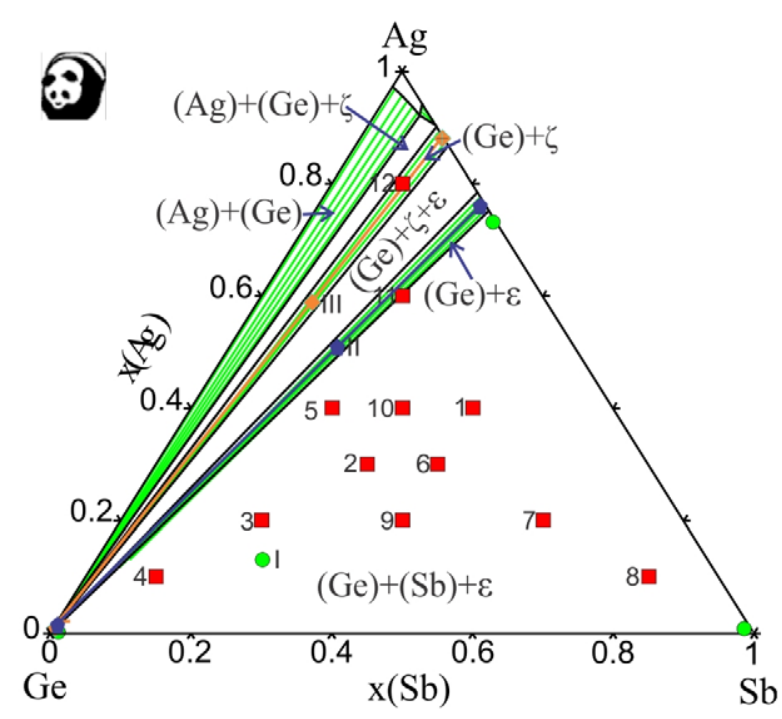

Fig. 1. Isothermal sections in ternary Ag-Ge-Sb systems at $300^{\circ} \mathrm{C}$.

Ag-Ge-Sb system was studied by a conventional metallographic analysis using a light microscopy and by SEM-EDS.

For optical microscopy, twelve alloy samples were selected. Compositions of the alloys, marked on the isothermal section of the ternary Ag-Ge-Sb system at $300^{\circ} \mathrm{C}$, are presented in Fig. 1. Compositions of the samples, analyzed by optical microscopy, are marked with a red square and the numbers from 1 to 12 and presented in Fig. 1. Twelve samples of the microstructure of alloys, whose compositions are marked in Fig. 1, are obtained by using optical microscopy, and shown in Fig. 2.

Three samples were tested with SEM-EDS analysis. Experimentally obtained phase compositions and overall compositions of individual samples are marked using identical symbols with the same color as are presented in Fig. 1. In Fig. 3, the microstructure of investigated alloys is presented.

In Fig. 1, we can see one larger and seven smaller regions. Three of them are three-phase $((\mathrm{Ge})+(\mathrm{Sb})$ $+\varepsilon,(\mathrm{Ge})+\varepsilon+\zeta$ and $(\mathrm{Ag})+(\mathrm{Ge})+\zeta)$, four of them are two-phase $((\mathrm{Ag})+(\mathrm{Ge}),(\mathrm{Ag})+\zeta,(\mathrm{Ge})+\zeta$ and $(\mathrm{Ge})+\varepsilon)$ and one is a single-phase $((\mathrm{Ag}))$ region. 

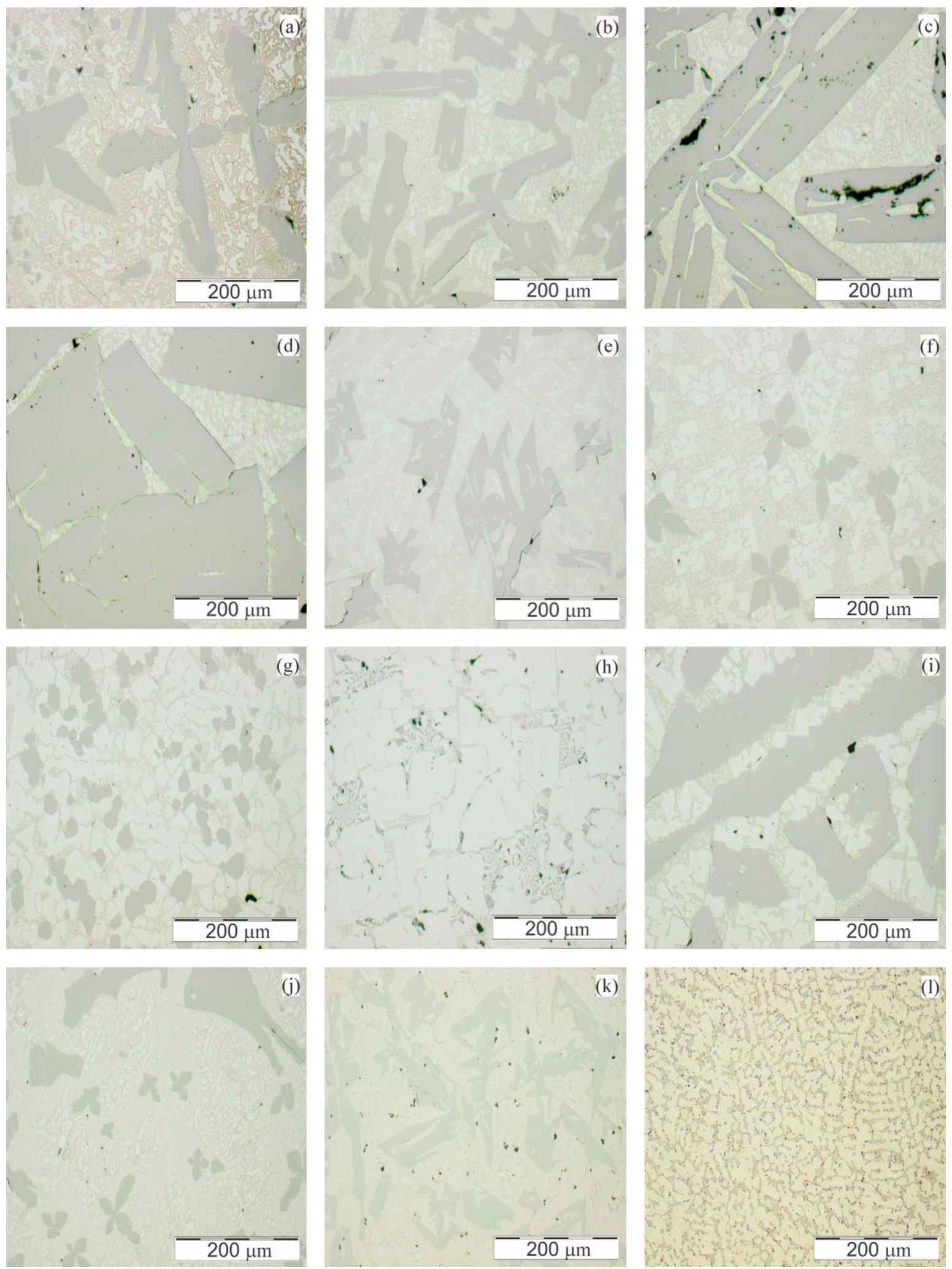

Fig. 2. Microstructures of the selected alloy samples (Sample 1 to 12, marked from (a) to (l), respectively).

Samples from 1 to 10 (Figs. $2 \mathrm{a}-\mathrm{j}$ ) consist of three phases $((\mathrm{Ge})+(\mathrm{Sb})+\varepsilon)$. In Figs. $2 \mathrm{a}-\mathrm{j}$, the samples from 1 to 10 consist of the darkest phase, which is rich in germanium $(\mathrm{Ge})$, the lighter phase is intermetal- lic silver-antimony $\varepsilon\left(\mathrm{Ag}_{3} \mathrm{Sb}\right)$, and the lightest phase is rich in antimony (Sb). Sample 11 (Fig. $2 \mathrm{k}$ ) is from two-phase $(\mathrm{Ge})+\varepsilon$ region, the darkest large grain phase is rich in germanium $(\mathrm{Ge})$, and the lighter phase is 

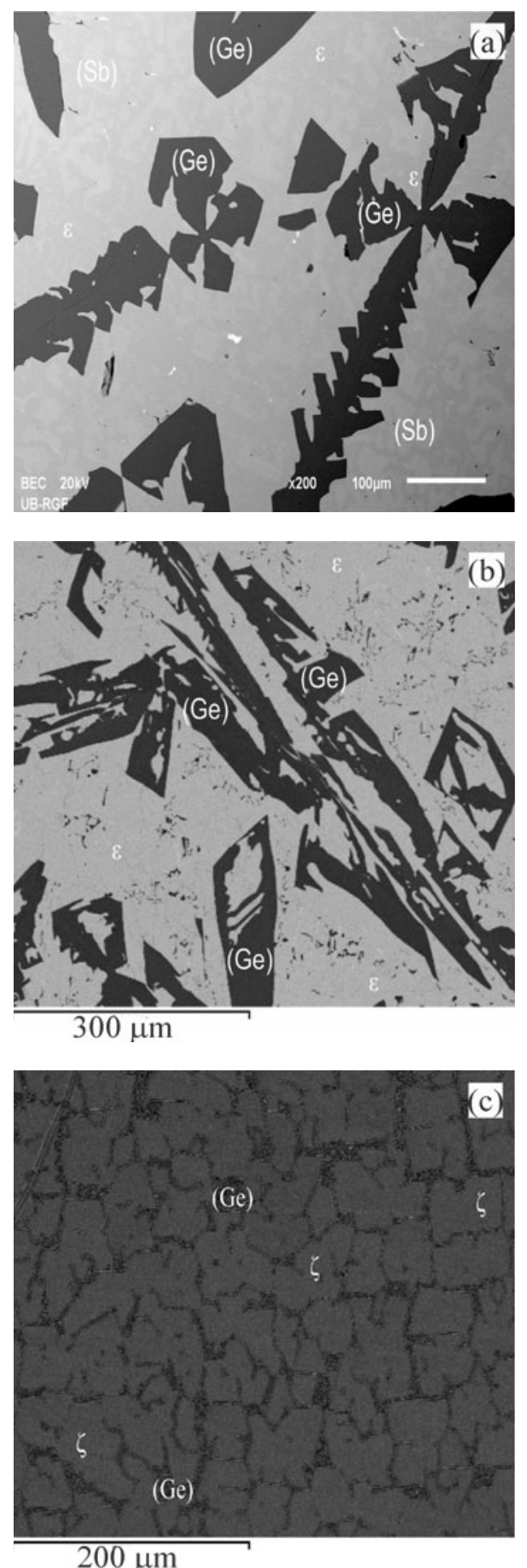

Fig. 3. Microstructures of the alloys analyzed by the SEM-EDS technique: (a) I $\left(\mathrm{Ag}_{13.03} \mathrm{Ge}_{63.37} \mathrm{Sb}_{23.60}\right)$, (b) II $\left(\mathrm{Ag}_{52.32} \mathrm{Ge}_{31.61} \mathrm{Sb}_{16.07}\right)$, and (c) III $\left(\mathrm{Ag}_{58.83} \mathrm{Ge}_{33.41} \mathrm{Sb}_{7.76}\right)$.

intermetallic silver-antimony $\varepsilon\left(\mathrm{Ag}_{3} \mathrm{Sb}\right)$. The last considered alloy presented in Fig. 21 is the sample 12 from two-phase $(\mathrm{Ge})+\zeta$ region. In Fig. 2l, the phase rich in germanium $(\mathrm{Ge})$ is the darkest mosaic phase, and the lighter phase is an intermetallic silver-antimony $\zeta\left(\mathrm{Ag}_{9} \mathrm{Sb}\right)$.

For better insight into the microstructure of the investigated alloys, three samples were analyzed by the SEM-EDS technique. These samples were selected from the same region as the samples observed by a light microscope.

The obtained SEM micrographs of the studied microstructures are presented in Fig. 3.

The microstructures of the selected alloys confirm predicted regions. Sample I is from three-phase region $((\mathrm{Ge})+(\mathrm{Sb})+\varepsilon)$. Samples II and III are from twophase regions $((\mathrm{Ge})+\varepsilon$ and $(\mathrm{Ge})+\zeta)$, respectively. In Fig. 3a, for the sample I ( $\left.\mathrm{Ag}_{13.03} \mathrm{Ge}_{63.37} \mathrm{Sb}_{23.60}\right)$ annealed at $300^{\circ} \mathrm{C}$, in SEM micrograph there are clearly visible three different phases. The dark phase represents primary solidified (Ge) crystals. Grey and bright areas in the base represent uniformly distributed $\varepsilon$ and (Sb) phases.

Experimentally determined phases, whose compositions are given in Table 2, show good agreement with the calculated phases. Microstructures obtained by SEM and their compositions determined by the EDS method confirm the calculated isothermal sections of the ternary $\mathrm{Ag}-\mathrm{Ge}-\mathrm{Sb}$ system at $300^{\circ} \mathrm{C}$.

\subsection{XRD analysis}

For XRD analysis, three alloys were selected. Compositions of these three alloys are marked in Fig. 1 with roman numbers from I to III. These are the same samples as those tested by SEM-EDS analysis.

An XRD analysis confirmed three regions. Experimentally obtained values for lattice parameters of identified phases and overall compositions of individual samples are presented in Table 3. Obtained values of lattice parameters for $(\mathrm{Ge})$ are in good agreement with literature data from Swanson et al. [18]. Formed (Ge) phase has a cubic crystal system with a space group $F d \overline{3} m$ and lattice parameter $a=5.632-5.652 \AA$. Phase ( $\mathrm{Sb}$ ) has a rhombohedral crystal system with a space group $R \overline{3} m$ and lattice parameter $a=4.273 \AA$, $c=11.338 \AA$ that is in agreement with data from Burrett et al. [19]. The next phase $\varepsilon\left(\mathrm{Ag}_{3} \mathrm{Sb}\right)$ has an orthorhombic crystal system with a space group $P m 2 m$ and lattice parameters range from $a=2.986-2.996 \AA$, $b=5.180-5.246 \AA, c=4.774-4.854 \AA$, and are in an accordance with the data from Westgren et al. [20]. The phase $\zeta\left(\mathrm{Ag}_{9} \mathrm{Sb}\right)$ is in agreement with the data from Petruk et al. [21], and the obtained parameters are for $a=2.953 \AA$ and $c=4.786 \AA$.

Our results, presented in Table 3 , are in good agreement with the previously published results [1821].

XRD pattern for the sample I with identified phases is shown in Fig. 4 as an illustration.

\subsection{Mechanical properties}

In the ternary Ag-Ge-Sb system, (Ge) phase oc- 
Ta ble 2. Predicted and experimentally determined phase compositions in the ternary $\mathrm{Ag}$-Ge-Sb system at $300{ }^{\circ} \mathrm{C}$

\begin{tabular}{|c|c|c|c|c|c|c|c|c|c|}
\hline \multirow{3}{*}{ Sample } & \multirow{3}{*}{$\begin{array}{c}\text { Overall } \\
\text { composition } \\
\text { (at.\%) }\end{array}$} & \multicolumn{2}{|c|}{ Determined phases } & \multicolumn{6}{|c|}{ Compositions of phases (at.\%) } \\
\hline & & \multirow{2}{*}{$\begin{array}{l}\text { Theore- } \\
\text { tical }\end{array}$} & \multirow{2}{*}{$\begin{array}{l}\text { SEM- } \\
\text { EDS }\end{array}$} & \multicolumn{2}{|c|}{$\mathrm{Ag}$} & \multicolumn{2}{|c|}{$\mathrm{Ge}$} & \multicolumn{2}{|l|}{$\mathrm{Sb}$} \\
\hline & & & & Exp. & Cal. & Exp. & Cal. & Exp. & Cal. \\
\hline I & $\begin{array}{l}63.37 \mathrm{Ge} \\
13.03 \mathrm{Ag} \\
23.60 \mathrm{Sb}\end{array}$ & $\begin{array}{c}(\mathrm{Ge}) \\
(\mathrm{Sb}) \\
\varepsilon\left(\mathrm{Ag}_{3} \mathrm{Sb}\right)\end{array}$ & $\begin{array}{c}(\mathrm{Ge}) \\
(\mathrm{Sb}) \\
\varepsilon\left(\mathrm{Ag}_{3} \mathrm{Sb}\right)\end{array}$ & $\begin{array}{c}0.14 \pm 0.7 \\
0.54 \pm 0.3 \\
73.15 \pm 0.9\end{array}$ & $\begin{array}{c}0.04 \\
- \\
74.45\end{array}$ & $\begin{array}{c}98.83 \pm 0.2 \\
0.69 \pm 0.4 \\
0.56 \pm 0.6\end{array}$ & $\begin{array}{c}99.44 \\
- \\
0.38\end{array}$ & $\begin{array}{c}1.03 \pm 0.8 \\
98.77 \pm 0.7 \\
26.29 \pm 0.6\end{array}$ & $\begin{array}{c}0.52 \\
100.00 \\
25.17\end{array}$ \\
\hline II & $\begin{array}{l}31.61 \mathrm{Ge} \\
52.32 \mathrm{Ag} \\
16.07 \mathrm{Sb}\end{array}$ & $\begin{array}{c}(\mathrm{Ge}) \\
\varepsilon\left(\mathrm{Ag}_{3} \mathrm{Sb}\right)\end{array}$ & $\begin{array}{c}(\mathrm{Ge}) \\
\varepsilon\left(\mathrm{Ag}_{3} \mathrm{Sb}\right)\end{array}$ & $\begin{array}{c}0.61 \pm 0.1 \\
75.83 \pm 0.4\end{array}$ & $\begin{array}{c}0.22 \\
76.01\end{array}$ & $\begin{array}{c}98.43 \pm 0.1 \\
0.26 \pm 0.5\end{array}$ & $\begin{array}{c}99.51 \\
0.18\end{array}$ & $\begin{array}{c}0.96 \pm 0.9 \\
23.91 \pm 0.3\end{array}$ & $\begin{array}{c}0.27 \\
23.81\end{array}$ \\
\hline III & $\begin{array}{c}33.41 \mathrm{Ge} \\
58.83 \mathrm{Ag} \\
7.76 \mathrm{Sb}\end{array}$ & $\begin{array}{c}(\mathrm{Ge}) \\
\zeta\left(\mathrm{Ag}_{9} \mathrm{Sb}\right)\end{array}$ & $\begin{array}{c}(\mathrm{Ge}) \\
\zeta\left(\mathrm{Ag}_{9} \mathrm{Sb}\right)\end{array}$ & $\begin{array}{c}0.60 \pm 0.2 \\
87.98 \pm 0.7\end{array}$ & $\begin{array}{c}0.04 \\
87.59\end{array}$ & $\begin{array}{c}98.43 \pm 0.4 \\
0.35 \pm 0.6\end{array}$ & $\begin{array}{c}99.74 \\
0.31\end{array}$ & $\begin{array}{c}0.97 \pm 0.8 \\
11.67 \pm 0.3\end{array}$ & $\begin{array}{c}0.22 \\
12.10\end{array}$ \\
\hline
\end{tabular}

Ta ble 3. Results of XRD analysis for Ag-Ge-Sb samples annealed at $300^{\circ} \mathrm{C}$

\begin{tabular}{|c|c|c|c|c|c|c|c|c|c|}
\hline \multirow{2}{*}{\multicolumn{2}{|c|}{$\begin{array}{c}\text { Overall } \\
\text { composition } \\
\text { (at.\%) }\end{array}$}} & \multicolumn{2}{|c|}{ Phase } & \multicolumn{6}{|c|}{ Lattice parameters $(\AA)$} \\
\hline & & Pred. & Ident. & & $a$ & & 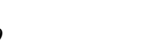 & & $c$ \\
\hline I & $\begin{array}{l}63.37 \mathrm{Ge} \\
13.03 \mathrm{Ag} \\
23.60 \mathrm{Sb}\end{array}$ & $\begin{array}{c}(\mathrm{Ge}) \\
(\mathrm{Sb}) \\
\varepsilon\left(\mathrm{Ag}_{3} \mathrm{Sb}\right)\end{array}$ & $\begin{array}{c}(\mathrm{Ge}) \\
(\mathrm{Sb}) \\
\varepsilon\left(\mathrm{Ag}_{3} \mathrm{Sb}\right)\end{array}$ & $\begin{array}{l}5.632(6) \\
4.273(9) \\
2.996(4)\end{array}$ & $\begin{array}{l}5.658[18] \\
4.308[19] \\
2.986[20]\end{array}$ & $5.236(1)$ & $5.180[20]$ & $\begin{array}{r}11.338(1) \\
4.847(2)\end{array}$ & $\begin{array}{r}11.274[19] \\
4.774[20]\end{array}$ \\
\hline II & $\begin{array}{l}31.61 \mathrm{Ge} \\
52.32 \mathrm{Ag} \\
16.07 \mathrm{Sb}\end{array}$ & $\begin{array}{c}(\mathrm{Ge}) \\
\varepsilon\left(\mathrm{Ag}_{3} \mathrm{Sb}\right)\end{array}$ & $\begin{array}{c}(\mathrm{Ge}) \\
\varepsilon\left(\mathrm{Ag}_{3} \mathrm{Sb}\right)\end{array}$ & $\begin{array}{l}5.648(2) \\
2.973(8)\end{array}$ & $\begin{array}{l}5.658[18] \\
2.986[20]\end{array}$ & $5.201(3)$ & $5.180[20]$ & $4.793(5)$ & $4.774[20]$ \\
\hline III & $\begin{array}{c}33.41 \mathrm{Ge} \\
58.83 \mathrm{Ag} \\
7.76 \mathrm{Sb}\end{array}$ & $\begin{array}{c}(\mathrm{Ge}) \\
\zeta\left(\mathrm{Ag}_{9} \mathrm{Sb}\right)\end{array}$ & $\begin{array}{c}(\mathrm{Ge}) \\
\zeta\left(\mathrm{Ag}_{9} \mathrm{Sb}\right)\end{array}$ & $\begin{array}{l}5.652(8) \\
2.953(1)\end{array}$ & $\begin{array}{l}5.658[18] \\
2.950[21]\end{array}$ & & & $4.786(1)$ & $4.770[21]$ \\
\hline
\end{tabular}

curs in all tested samples. For this reason, the pure germanium sample with oval shape was prepared for testing Vickers microhardness. The load of $0.245 \mathrm{~N}$ was applied and time of loading was 20 s. 35 measurements were carried out in five rows by seven measurements. In Table 4, the values of measured Vickers microhardness are presented. The mean value based on 35 measurements is $858.30 \mathrm{MN} \mathrm{m}^{-2}$. In Fig. 5, the micrographs of indentations on pure (Ge) are presented.

Vickers microhardness was investigated for 12 alloys. Compositions of these 12 alloys are presented in Fig. 1. The load of $0.245 \mathrm{~N}$ was applied and time of loading was $20 \mathrm{~s}$. The values of Vickers microhardness with micrographs of four samples are presented in Table 5. Vickers microhardness for each phase was determined by five measurements.

The obtained values presented in Table 5 indicate that the hardness of solid solution $(\mathrm{Ge})$ is in the range

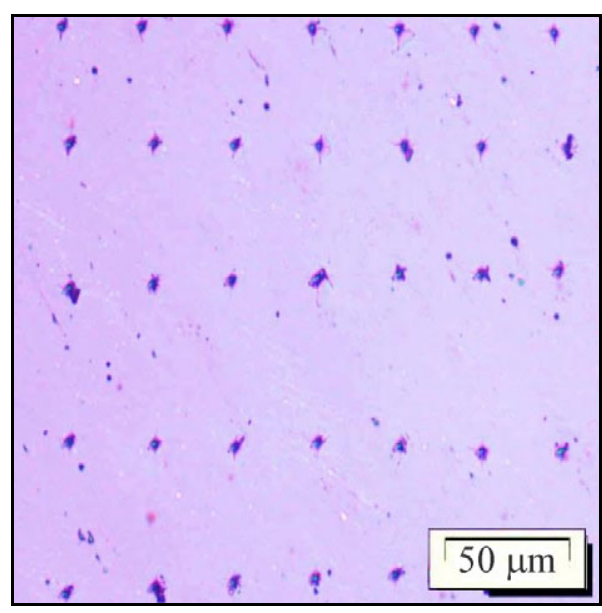

Fig. 5. Micrographs of the indentations on pure Ge. 
Table 4. Measured Vickers microhardness of the pure germanium

\begin{tabular}{cccccccc}
\hline & \multicolumn{7}{c}{ Vickers microhardness of different tests $\left(\mathrm{MN} \mathrm{m}^{-2}\right)$} \\
\cline { 2 - 8 } order & 1 & 2 & 3 & 4 & 5 & 6 & 7 \\
\hline & 854.24 & 863.09 & 851.17 & 851.92 & 874.76 & 857.37 & 855.06 \\
2 & 858.95 & 858.21 & 851.92 & 857.01 & 857.37 & 851.85 & 851.92 \\
3 & 856.54 & 854.76 & 867.28 & 858.16 & 850.42 & 851.17 & 858.95 \\
4 & 858.24 & 875.76 & 853.23 & 856.63 & 876.23 & 856.32 & 855.23 \\
5 & 878.21 & 861.32 & 850.42 & 856.36 & 855.71 & 857.38 & 857.31 \\
\hline
\end{tabular}

Table 5. Measured Vickers microhardness of the phases in ternary Ag-Ge-Sb system

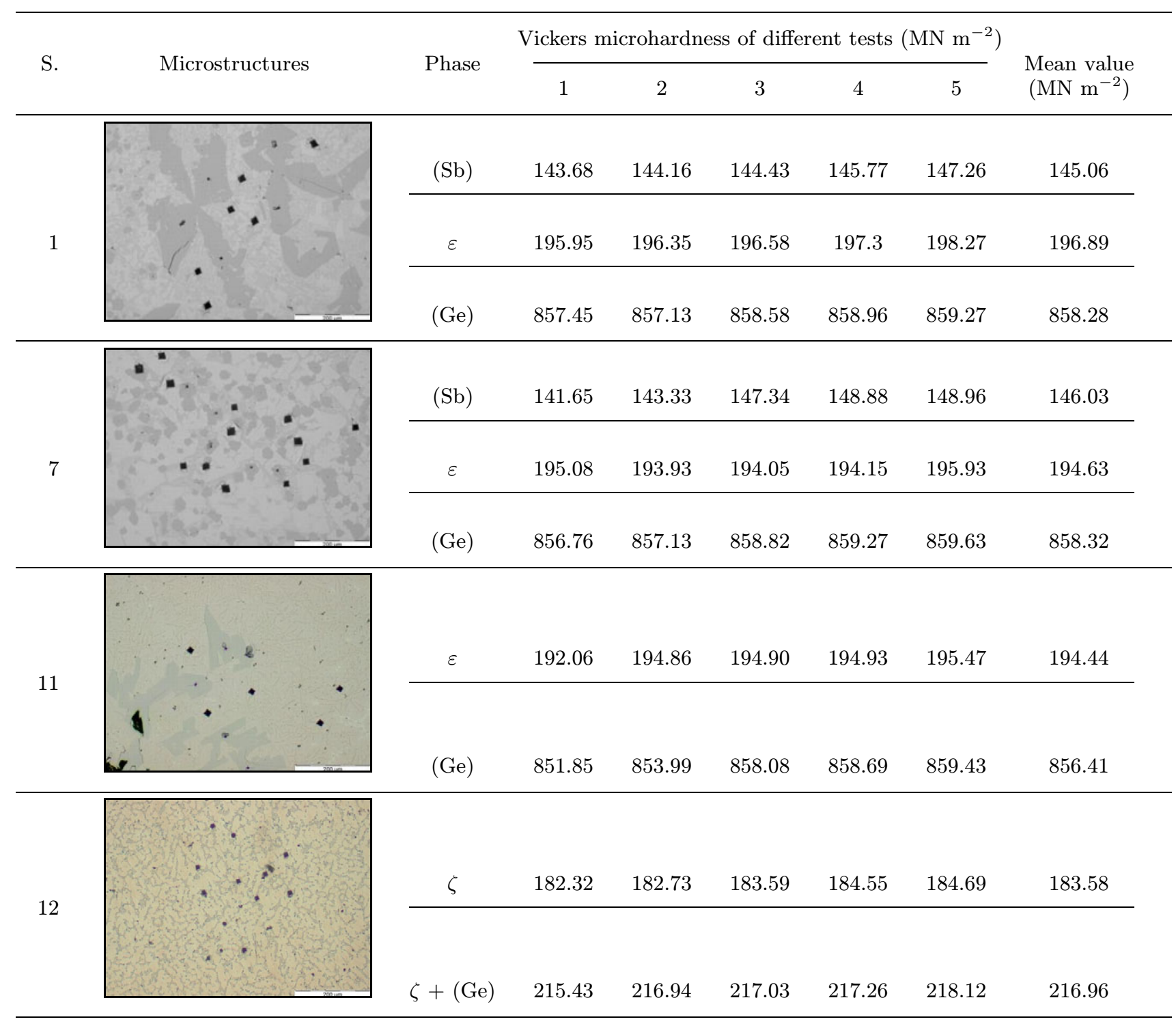

from 856.41 to $858.32 \mathrm{MN} \mathrm{m}^{-2}$, for solid solution $(\mathrm{Sb})$ is from 145.03 to $146.06 \mathrm{MN} \mathrm{m}^{-2}$, for intermetallic compound $\varepsilon$ is from 194.44 to $196.89 \mathrm{MN} \mathrm{m}^{-2}$, and the last one investigated intermetallic compound is $\zeta$, for this phase we obtained the value $183.58 \mathrm{MN} \mathrm{m}^{-2}$.

After the measurements of phase hardness, the ex- periment was continued by a hardness test by Brinell method. Compositions of the investigated alloys and hardness are given in Table 6.

Graphical presentation of the relation hardness vs. molar ratio within the considered vertical sections is shown in Fig. 6. Hardness values by Brinell method 
Table 6. Brinell hardness of the alloys of the ternary Ag-Ge-Sb system

\begin{tabular}{|c|c|c|c|c|c|c|}
\hline \multicolumn{3}{|c|}{ Mole fraction of components } & \multicolumn{3}{|c|}{ Value $\left(\mathrm{MN} \mathrm{m}^{-2}\right)$} & \multirow{2}{*}{ Mean value $\left(\mathrm{MN} \mathrm{m}^{-2}\right)$} \\
\hline$x(\mathrm{Ge})$ & $x(\mathrm{Sb})$ & $x(\mathrm{Ag})$ & 1 & 2 & 3 & \\
\hline $\mathbf{0}$ & 0.5 & 0.5 & 146.20 & 146.90 & 147.30 & 146.80 \\
\hline 0.2 & 0.4 & 0.4 & 106.60 & 98.10 & 90.80 & 98.50 \\
\hline 0.4 & 0.3 & 0.3 & 106.40 & 105.90 & 104.10 & 105.50 \\
\hline 0.6 & 0.2 & 0.2 & 139.90 & 130.80 & 124.10 & 131.60 \\
\hline 0.8 & 0.1 & 0.1 & 209.30 & 200.10 & 198.30 & 202.60 \\
\hline 0.5 & $\mathbf{0}$ & 0.5 & 162.10 & 162.20 & 162.30 & 162.20 \\
\hline 0.4 & 0.2 & 0.4 & 134.50 & 132.50 & 132.40 & 133.10 \\
\hline 0.3 & 0.4 & 0.3 & 134.50 & 129.60 & 125.50 & 129.80 \\
\hline 0.2 & 0.6 & 0.2 & 133.80 & 133.50 & 132.10 & 133.10 \\
\hline 0.1 & 0.8 & 0.1 & 162.30 & 157.00 & 153.10 & 157.40 \\
\hline 0 & 1 & 0 & 294.00 & - & - & 294.00 \\
\hline 0.5 & 0.5 & 0 & 165.70 & 166.10 & 166.20 & 166.00 \\
\hline 0.4 & 0.4 & 0.2 & 129.80 & 127.10 & 122.70 & 126.50 \\
\hline 0.3 & 0.3 & 0.4 & 114.00 & 109.70 & 104.50 & 109.40 \\
\hline 0.2 & 0.2 & 0.6 & 106.30 & 106.10 & 104.50 & 105.60 \\
\hline 0.1 & 0.1 & 0.8 & 90.10 & 83.40 & 80.90 & 84.80 \\
\hline 0 & 0 & 1 & 24.50 & - & - & 24.50 \\
\hline
\end{tabular}

Table 7 . Electrical conductivity of the alloys from isothermal sections at $300^{\circ} \mathrm{C}$

\begin{tabular}{|c|c|c|c|c|c|c|c|}
\hline \multicolumn{3}{|c|}{ Mole fraction of components } & \multicolumn{4}{|c|}{ Value $\left(\mathrm{MS} \mathrm{m}^{-2}\right)$} & \multirow{2}{*}{ Mean value $\left(\mathrm{MS} \mathrm{m}^{-2}\right)$} \\
\hline$x(\mathrm{Ge})$ & $x(\mathrm{Sb})$ & $x(\mathrm{Ag})$ & 1 & 2 & 3 & 4 & \\
\hline $\mathbf{0}$ & 0.5 & 0.5 & 2.059 & 2.138 & 2.097 & 2.242 & 2.134 \\
\hline 0.2 & 0.4 & 0.4 & 1.180 & 1.129 & 1.058 & 1.092 & 1.115 \\
\hline 0.4 & 0.3 & 0.3 & 1.200 & 1.175 & 1.189 & 1.191 & 1.189 \\
\hline 0.6 & 0.2 & 0.2 & 0.798 & 0.864 & 0.912 & 0.898 & 0.868 \\
\hline 0.8 & 0.1 & 0.1 & 0.975 & 0.933 & 0.952 & 0.988 & 0.962 \\
\hline 1 & 0 & 0 & 1.347 & 1.339 & 1.343 & 1.346 & 1.344 \\
\hline 0.5 & $\mathbf{0}$ & 0.5 & 1.633 & 1.621 & 1.597 & 1.649 & 1.625 \\
\hline 0.4 & 0.2 & 0.4 & 1.559 & 1.530 & 1.600 & 1.479 & 1.542 \\
\hline 0.3 & 0.4 & 0.3 & 0.937 & 0.896 & 0.917 & 0.918 & 0.917 \\
\hline 0.2 & 0.6 & 0.2 & 0.590 & 0.613 & 0.623 & 0.622 & 0.612 \\
\hline 0.1 & 0.8 & 0.1 & 1.209 & 1.273 & 1.298 & 1.376 & 1.289 \\
\hline 0 & 1 & 0 & 2.882 & 2.877 & 2.893 & 2.885 & 2.884 \\
\hline 0.5 & 0.5 & 0 & 0.343 & 0.341 & 0.353 & 0.344 & 0.345 \\
\hline 0.4 & 0.4 & 0.2 & 0.609 & 0.606 & 0.603 & 0.605 & 0.606 \\
\hline 0.3 & 0.3 & 0.4 & 0.698 & 0.691 & 0.692 & 0.692 & 0.693 \\
\hline 0.2 & 0.2 & 0.6 & 0.520 & 0.502 & 0.504 & 0.521 & 0.512 \\
\hline 0.1 & 0.1 & 0.8 & 10.541 & 10.530 & 10.492 & 10.510 & 10.518 \\
\hline 0 & 0 & 1 & 62.00 & - & - & - & 62.00 \\
\hline
\end{tabular}

for pure $\mathrm{Sb}$ and $\mathrm{Ag}$ were taken from [22].

An increase in hardness with increasing molar ratio of the corresponding metal is clearly visible, which is in agreement with the results presented in Figs. 6a,b. In Fig. 6c, a decline of hardness with increasing molar ratio is clearly visible.

\subsection{Electrical conductivity}

Electrical conductivities of the alloys from the isothermal sections at $300^{\circ} \mathrm{C}$ were determined experimentally. The obtained values of electrical con- ductivity of the studied alloys are presented in Table 7 .

Graphical presentation of the correlation between electrical conductivity and mole fraction of components for all investigated samples is shown in Fig. 7.

It is clearly visible that the ternary alloy $\mathrm{Ag}_{80} \mathrm{Ge}_{10}$ $\mathrm{Sb}_{10}$ has the highest electrical conductivity 10.518 MS $\mathrm{m}^{-1}$, and this is in accordance with the results presented in Fig. 7c and Table 7. This was expected because, in this combination of ternary alloys, silver has a significantly higher electrical conductivity than the other two components. 

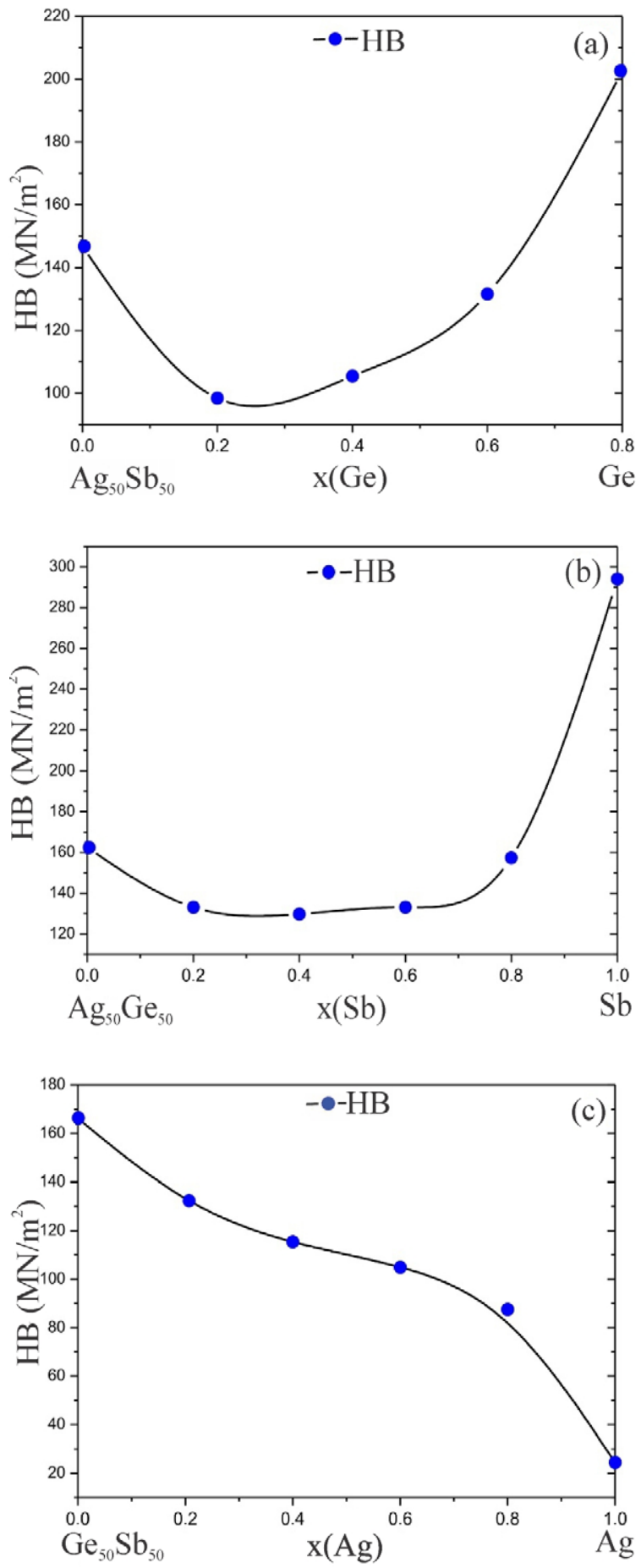

Fig. 6. Brinell hardness for investigated samples from isothermal sections at $300^{\circ} \mathrm{C}$ : (a) Ge-AgSb, (b) Sb-AgGe and (c) Ag-GeSb.

\section{Conclusions}

The isothermal section of the ternary Ag-Ge-Sb system at $300{ }^{\circ} \mathrm{C}$ was investigated in details. By using thermodynamic parameters from literature, the isothermal section of the ternary Ag-Ge-Sb system at
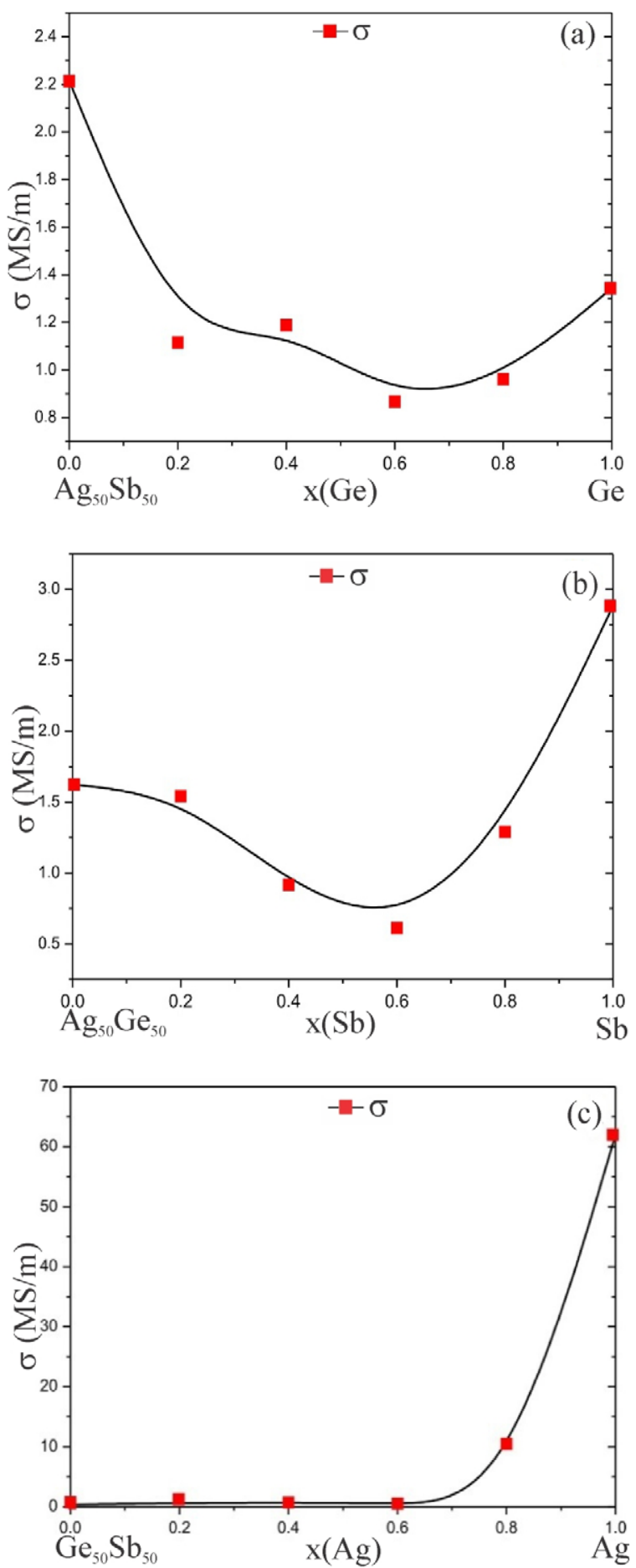

Fig. 7. Electrical conductivity for investigated samples from isothermal sections at $30{ }^{\circ} \mathrm{C}$ : (a) $\mathrm{Ge}-\mathrm{Ag}_{50} \mathrm{Sb}_{50}$, (b) $\mathrm{Sb}-\mathrm{Ag}_{50} \mathrm{Ge}_{50}$, and (c) $\mathrm{Ag}-\mathrm{Ge}_{50} \mathrm{Sb}_{50}$.

$30{ }^{\circ} \mathrm{C}$ has been calculated using Pandat 8.1 software.

Calculated isothermal section at $300{ }^{\circ} \mathrm{C}$ is, in general, agreement with the results of microstructural investigations of annealed samples obtained by light microscopy, SEM-EDS, and XRD analysis. Lattice pa- 
rameters of identified phases were determined using XRD analysis and compared with literature data.

Good overall agreement between experimental and calculated values was obtained. Furthermore, Vickers microhardness of pure germanium was determined. Also, Vickers microhardness measurements were carried out for the phases present in the microstructure of twelve alloy samples. Values of Brinell hardness and electrical conductivity for selected samples are also presented in this paper.

\section{Acknowledgements}

This work was supported by the Ministry of Science of the Republic of Serbia (Project No. 172037). Calculations were performed by Pandat 8.1 software.

\section{References}

[1] Premović, M., Manasijević, D., Minić, D., Živković, D.: J. Alloy. Compd., 610, 2014, p. 161. doi:10.1016/j.jallcom.2014.04.208

[2] Wang, J., Leinenbach, C., Roth, M.: J. Alloy. Compd., 485, 2009, p. 577. doi:10.1016/j.jallcom.2009.06.030

[3] Premović, M., Minić, D., Cosović, V., Manasijević, D., Živković, D.: Metall. Mater. Trans. A, 45, 2014, p. 4829. doi:10.1007/S11661-014-2445-4

[4] Ielmini, D., Lacaita, A. L.: Mater. Today, 14, 2011, p. 600.

[5] Ćosović, V., Talijan, N., Živković, D., Minić, D., Živković, Ž.: J. Min. Metall. Sect. B-Metall., 48, 2012, p. 131. doi:10.2298/JMMB111101013C

[6] Talijan, N., Cosović, V., Stajić Trošić, J., Grujić, A., Živković, D., Romhanji, E.: J. Min. Metall. Sect. BMetall., 43, 2007, p. 171. doi:10.2298/JMMB0702171T

[7] Kostov, A., Živković, D., Zivković, Z.: Thermochim. Acta, 338, 1999, p. 35.
[8] Kostov, A., Živković, D., Živković, Z.: J. Therm. Anal. Calorim., 60, 2000, p. 473. doi:10.1023/A:1010170215647

[9] del Pozo, J. M., Diaz, L.: J. Non-Crystalline Solids, 243, 1999, p. 45.

[10] Minić, D., Aljilji, A., Kolarević, M., Manasijević, D., Živković, D.: High Temp. Mater. Proc., 30, 2011, p. 131. doi:10.1515/HTMP.2010.019

[11] Ćosović, V., Minić, D., Manasijević, D., Kolarević, M., Talijan, N., Živković, D.: Kovove Mater., 50, 2012, p. 161.

[12] Wang, J., Liu, Y. J., Tang, C. Y., Liu, L. B., Zhou, H. Y., Jin, Z. P.: Thermochim. Acta, 512, 2011, p. 240. doi:10.1016/j.tca.2010.11.003

[13] Liu, J., Guo, C., Li, C., Du, Z.: Thermochim. Acta, 520, 2011, p. 38. doi:10.1016/j.tca.2011.03.008

[14] Zoro, E., Servant, C., Legendre, B.: J. Phase Equilib. Diffus., 28, 2007, p. 250. doi:10.1007/s11669-007-9085-y

[15] Cao, W., Chen, S.-L., Zhang, F., Wu, K., Yang, Y., Chang, Y. A., Schmid-Fetzer, R., Oates, W. A.: Calphad, 33, 2009, p. 328. doi:10.1016/j.calphad.2008.08.004

[16] Dinsdale, A. T., Watson, A., Kroupa, A., Vřeštál, J., Zemanová, A., Vizdal, J. (Eds.): COST Action 531 - Atlas of Lead Free Soldering. Volume 1. Belgium, COST Office 2008.

[17] Gupta, K. P.: Section II: Phase Diagram Evaluations. JPEDAV, 30, 2009, p. 398.

[18] Swanson, H. E., Tatge, E.: Natl. Bur. Stand. US Circ., 359, 1953, p. 1.

[19] Barrett, C. S., Cucka, P., Haefner, K.: Acta Crystallogr., 16, 1963, p. 451. doi: $10.1107 / \mathrm{S} 0365110 \mathrm{X} 63001262$

[20] Westgren, A., Hagg, G., Eriksson, S.: Z. Phys. Chem. B, 4, 1929, p. 461

[21] Petruk, W., Cabri, L. J., Harris, D. C., Stewart, J. M., Clark, L. A.: J. Mater. Sci., 16, 1981, p. 1522. doi:10.1007/BF02396869

[22] http://www.webelements.com/periodicity/ hardness_brinell (27.08.2014) 